
\title{
$\begin{array}{ll}\text { Research Square } & \begin{array}{l}\text { Preprints are preliminary reports that have not undergone peer review. } \\ \text { They should not be considered conclusive, used to inform clinical practice, } \\ \text { or referenced by the media as validated information. }\end{array}\end{array}$
}

\section{Evaluation of prosthetic complications and tumor recurrence with the single energy metal artifact reduction algorithm in patients with hip tumor prostheses}

Fangling Zhang

Sun Yat-Sen University Guanghua School of Stomatology, Hospital of stomatology

Xiaoling Zhang

The First Affiliated Hospital, Sun Yat-sen University

Ling Ma

Sun Yat-sen University First Affiliated Hospital

Ruocheng Li

The First Affiliated Hospital, Sun Yat-sen University

Zhaohui Zhang

The First Affiliated Hospital, Sun Yat-sen University

Donglin Zeng

Sun Yat-Sen University Guanghua School of Stomatology, Hospital of stomatology

Lei Ding ( $\square$ dinglei3@mail.sysu.edu.cn)

Sun Yat-sen University First Affiliated Hospital

\section{Research article}

Keywords: Metal artifact reduction, Hip tumor prostheses, Prosthetic complication, Tumor recurrence, Computed tomography

Posted Date: December 7th, 2020

DOI: https://doi.org/10.21203/rs.3.rs-121132/v1

License: () (i) This work is licensed under a Creative Commons Attribution 4.0 International License. Read Full License 


\section{Abstract}

Background: To evaluate the effectiveness of the single energy metal artifact reduction (SEMAR) algorithm with a second-generation 320-row multidetector computed tomography (MDCT) on complications and tumor recurrence detection in patients with hip tumor prostheses.

Methods: From February 2016 to June 2019, 31consecutive patients with tumor prostheses of the hip joint underwent CT scans. Lesions were confirmed by histology or clinical and imaging follow-up. Images were reconstructed using 2 methods: iterative (IR) algorithm alone and SEMAR algorithm (IR+ SEMAR). Two radiologists graded the image quality visually by a 6-point (from 0 to 5 ) ordinal scale. Standard deviations (SD) of CT attenuation value defined as the artifact index (AI) were compared between the two reconstructed methods. Paired sample $t$-test was adopted to compare the Al values on IR and SEMAR images. Wilcoxon matched-pairs signed rank test was performed to compare the visual scores on IR and SEMAR images. A $p$-value less than 0.05 was considered statistically significant.

Results: The artifacts of the SEMAR images were reduced compared to the Non-SEMAR images $(113.94 \pm 128.54 \mathrm{vs} 35.98 \pm 53.75 \mathrm{HU} \otimes t=2.867, P<0.05)$. 20 and 16 more lesions were detected by observer 1 and observer 2 with SEMAR algorithm respectively. The mean scores of lesions without SEMAR were $1.39 \pm 1.45$ (observer 1 ) and 1.55 \pm 1.34 (observer 2); with SEMAR, the scores were significantly higher, $4.42 \pm 0.56(z=-4.752, p<0.001)$ and $4.54 \pm 0.72$ $(z=-4.837, p<0.001)$ respectively.

Conclusion: The SEMAR algorithm can effectively reduce metal artifacts in patients with hip tumor prostheses and increase the diagnostic accuracy of prosthetic complications and tumor recurrence.

\section{Background}

With the number of hip tumor patients undergoing joint replacement gradually increased in recent years, imaging follow-up is important in determining whether tumors recur and potentially complications happen. Metallic hardware can cause severe artifacts on computed tomography (CT) images in the form of dark and bright streaks or bands due to scattering, x-ray beam hardening and photon starvation, partial volume effect and patient motion, significantly degrading image quality and diagnostic accuracy ${ }^{[1-3]}$. Metal artifact reduction (MAR) reconstruction algorithms that can ideally reduce or even eliminate image artifacts are urgently needed ${ }^{[4,5]}$. In the past decades, various MAR algorithms from different vendors have been reported for clinical use to reduce metal artifacts. The single-energy metal artifact reduction (SEMAR) algorithm was clinically used on a second-generation 320 -row multi-detector computed tomography (MDCT) recently. Previous studies have demonstrated the effectiveness of SEMAR in patients with dental filling, hip prosthesis and metal coil ${ }^{[6-8]}$. Although several authors have demonstrated the satisfactory effect of SEMAR on the visualization of bone-prosthesis interface, periarticular soft structures and pelvic organs in total hip prosthesis patients, our study mainly focused on the value of SEMAR on the follow-up of tumor recurrence and prosthetic complications in patients with hip tumor prosthesis.

\section{Methods}

\section{Patients}

From February 2016 to June 2019, 31 symptomatic patients with hip tumor prostheses (Beijing Lidakang Technology Co., Ltd, China) underwent 320-row MDCT scans (23 males, 8 females; mean age: $35.81 \pm 14.88$ years, range: 10-63 years). Preoperative tumors consisted of 10 osteosarcomas, 6 chondrosarcomas, 5 giant cell tumors, 3 Ewing's sarcomas, 2 fibrous histiocytomas, 2 metastatic tumors, 1 aneurysmal bone cyst, and 1 fibrosarcoma. The right side was involved 14 times, and the left side was involved 17 times. Detailed information of patients was showed in Table1. Tumor recurrence and prosthetic complications were confirmed by histology or clinical and imaging follow-up. This study was approved by the hospital ethics committee, and the need for signed informed consent was waived.

\section{Image acquisition and reconstruction}

CT images were acquired by a 320-row MDCT scanner (Aquilion ONE, Canon Medical Systems, Otawara, Japan) in helical mode. The axial scan parameters were as follows: tube voltage, $135 \mathrm{kV}$; tube current, automatic exposure control (SURE exposure 3D, Canon Medical Systems, Otawara, Japan); detector collimation, $320 \times 0.5 \mathrm{~mm}$; gantry rotation time, $1.0 \mathrm{~s}$; matrix $512 \times 512$. Contrast agent with an iodine concentration of $300 \mathrm{mg} / \mathrm{ml}$ (Ultravist 300 , Bayer AG, Berlin, Germany) were used in all the patients after plain scan. The total volume of contrast material (ml) was determined by multiplying the body weight $(\mathrm{kg})$ by two, with an upper limit of $100 \mathrm{ml}$. It was injected at a rate of $2.5 \mathrm{ml} / \mathrm{s}$ via a 22-gauge intravenous catheter placed in an antecubital vein. The enhanced CT scan began $70 \mathrm{~s}$ after the initiation of contrast injection. Adaptive IR algorithm (AIDR 3D, Canon Medical Systems) and IR + SEMAR algorithm (Canon Medical Systems) were applied to the raw data for each patient. Standard soft tissue kernel (FC08) and bone kernel (FC30) were used for the reconstructions with IR alone and IR+SEMAR respectively. The SEMAR images were reconstructed according to the published methods ${ }^{[8,9]}$.

\section{Image analysis}

\section{Subjective image assessment}

Images with IR/SEMAR were evaluated by two board-certified radiologists with 15 and 5 years of experience blindly and independently. Axial enhanced images with a 40/400 Hounsfield unit (HU) window width/level setting for soft tissue evaluation and 400/2200 HU window width/level setting for bone evaluation were showed randomly and on a high-resolution 20-inch monitor (M21, Jusha『Nanjing, China). The visual scores of lesions was graded as 
follows: $0=$ completely obscured; $1=$ marked artifacts with questionable recognition; $2=$ faint anatomic recognition; $3=$ recognition with low confidence; $4=$ recognition with medium confidence; $5=$ recognition with high confidence ${ }^{[8,10]}$.

Objective image assessment: comparison of artifact index (AI)

For each patient, circular regions of interest (ROI) were drawn within the lesions on enhanced images with different reconstructive methods and kept the same size at the same axial level, approximately $50-80 \mathrm{~mm}^{2}$. To quantify the image noise, the standard deviation (SD) of CT attenuation value defined as Al was measured ${ }^{[11,12]}$.

\section{Statistical analysis}

Statistical analysis was performed by SPSS 20.0 software (SPSS Inc. Chicago, IL, USA). Paired sample $t$-test was used to compare the Al values of IR and SEMAR images. Wilcoxon matched-pairs signed rank test was adopted to compare the scores between the two reconstruction methods. Intra-class correlation coefficient (ICC) was calculated to evaluate inter-observers' variability. A p-value less than 0.05 was considered statistically significant.

\section{Results}

Subjective image assessment

On SEMAR images, 6 patients with periprosthetic soft tissue infection, 8 patients with fluid collection, 2 patients with heterotopic ossification, 2 patients with periprosthetic osteolysis, and 13 patients with tumor recurrence were diagnosed. On IR images, 11 and 15 lesions were detected by observer 1 and observer 2 respectively, and the numbers increased to 31 and 31 with SEMAR algorithm. The SEMAR algorithm made more lesions identified (an increase of $64.5 \%$ and $51.6 \%$ by observer 1 and observer 2 ). The mean score of lesions with IR was $1.39 \pm 1.45$ and $1.55 \pm 1.34$ for observer 1 and observer 2 , respectively; with SEMAR, the corresponding scores were significantly higher to $4.42 \pm 0.56$ and $4.54 \pm 0.72(z=-4.752, p<0.001$ and $z=-4.837, p<0.001)$. Inter-observers' agreement was considered to be excellent (ICC=0.967). Representative cases were shown in Fig1 and Fig2.

Objective image assessment: comparison of Al

The mean Al values with IR and SEMAR were $113.94 \pm 128.54$ and $35.98 \pm 53.75 \mathrm{HU}$ respectively. The difference in Al was significant statistically $(t=2.867$, $P<0.05)$.

\section{Discussion}

There are many potential complications of hip arthroplasty, such as leg length discrepancy, prosthetic loosening, subluxation or dislocation and abnormalities of bones or soft tissues(periprosthetic fracture and osteolysis,periprosthetic soft tissue fluid collections, infection and heterotopic ossification $)^{[13]}$. CT can be used to supplement the radiograph to assess the symptomatic hip prostheses[especially for the peri-implant fluid collection and soft-tissue infection. However, artifacts from the prosthetic hip joint make the follow-up remain challenging. SEMAR is an algorithm that works with the single-energy mode and is applicable to routine data retrospectively $[6,14,15]$. There have been no published articles regarding the usefulness of the SEMAR on evaluating post-hip tumor prosthesis complications and tumor recurrence. Although Gondim Teixeira et al. reported the effectiveness of the SEMAR in patients with hip prostheses, the focus of their study was the visualization of specific periarticular normal muscles and pelvic organs rather than post-arthroplasty lesions and their study population was not tumor patients ${ }^{[8]}$.

Infection is the most serious complication, happening in 0.3 to $1.7 \%$ of hip arthroplasties and the frequency is increasing ${ }^{[16]}$. In our study, the most common prosthetic complication was periprosthetic fluid collection (8/18) and the following is soft tissue infection (6/18), which was higher than that reported in previous studies. Inclusion criteria (patient with symptomatic hip tumor prosthesis) may be account for this phenomenon. Our results showed that the SEMAR algorithm can potentially increase the performance of CT in the follow-up of hip tumor prostheses. Compared with the IR algorithm, the SEMAR technique can substantially reduce artifacts of hip tumor prostheses and improve lesion detectability. Not only did both observers detect more anomalies, but also the diagnostic confidence also increased (visual scores were significantly improved). Inter-observer agreement was considered to be excellent between the experienced and young radiologists. Moreover, the SEMAR algorithm has been used mostly on volume scan clinically at present. The 320-row MDCT system yields 16 -cm-range volume data ${ }^{[7]}$, which limits the clinical applicability when the range is wider than $16 \mathrm{~cm}$. We showed successful MAR effect with SEMAR by helical scan and the depiction of each anomaly was significantly improved.

The effectiveness of MAR algorithms differs from different vendors. Previous studies reported the effectiveness of different MAR algorithms on hip prosthesis phantom. MAR algorithm for orthopedic implants (O-MAR) (Philips Ingenuity Core CT), SEMAR algorithm (Canon Aquilion ONE CT), MAR software combined with monoenergetic reconstruction of DECT data (MARS) (GE Discovery 750HDCT) and monoenergetic reconstruction (Siemens SOMATOM Definition Flash CT $)^{[17]}$ can lead to decrease of artifacts in ROls both adjacent to the head of the prostheses and also between the prostheses. Jessie $Y$ Huang also reported that MARS was the most effective method in reducing streak artifacts of the pelvic phantom with hip prosthesis among 0 MAR, GE's monochromatic imaging of dual-energy CT and MARS ${ }^{[18]}$. Projection-based MAR algorithms, such as O-MAR, SEMAR, are primarily introduced to compensate for photon starvation phenomenon, whereas virtual monochromatic images obtained with dual-energy CT mainly reduce artifacts caused by beam hardening effect. Bright and dark band artifacts caused by photon starvation from large metallic hardware and from metal with high atomic numbers, for example hip prosthesis and endovascular coil, are too strong for the dual-energy CT alone to be removed ${ }^{[3,19]}$. Hence, the projection-based 
MAR algorithms become more effective than the monochromatic imaging of dual-energy CT in this situation. In this study, although the overall image quality was greatly improved by SEMAR, there was still a small remnant of artifacts, suggesting the SEMAR technique with Canon Medical Systems could not eliminate metal artifacts. Moreover, newly developed artifacts can be seen when the SEMAR algorithm was used for several reasons according to

previous studies ${ }^{[17,20]}$. These new artifacts were especially evident when the SEMAR was combined with IR. New high-density artifacts were also observed on the SEMAR images in our study. However, we were not able to make comparison among the SEMAR and other algorithms/techniques in patients with hip tumor prostheses. This is work that should be performed in future.

Our study has several limitations. First, only a small number of patients were included. Second, considering the retrospective nature of this study, further prospective studies are needed to verify the effectiveness of SEMAR algorithm.

\section{Conclusion}

Based on this study, we can conclude that SEMAR algorithm can effectively reduce the metal artifacts of hip tumor prostheses and is ideal in the evaluation of prosthetic complications and tumor recurrence.

\section{Abbreviations}

SEMAR』single energy metal artifact reduction

MDCTImulti-detector computed tomography

IRDiterative

SDIStandard deviations

CTLcomputed tomography

MARDMetal artifact reduction

HUDHounsfield unit

Allartifact index

ROIロregion of interest (

ICCDIntra-class correlation coefficient

\section{Declarations}

\section{Ethics Approval and Consent to Participate}

The current study was approved by the Institutional Ethics Committee of the First Affiliated Hospital of Sun Yat-Sen University, and the need for signed informed consent was waived.

\section{Consent for publication}

Not applicable.

\section{Availability of data and materials}

The dataset supporting the conclusions of this article is included within the article. Data and materials during the current study are available from the corresponding author upon reasonable request.

\section{Competing interests}

The authors declare that they have no competing interests.

\section{Funding}

Not applicable.

\section{Acknowledgements}

Not applicable.

\section{Authors' Contributions}


FLZ and XLZ participated in the design of the study, collected the patients' data, and drafted the manuscript. LM, ZZH, LD and RCL processed the figures, helped draft the manuscript, and performed a critical revision of the manuscript. LD conceived and designed the study and supervised the project. All authors read and approved the final version of the manuscript.

\section{References}

[1] Barrett JF, Keat N. Artifacts in CT: recognition and avoidance. Radiographics. 2004. 24(6): 1679-91.

[2] Bazalova M, Beaulieu L, Palefsky S, Verhaegena F. Correction of CT artifacts and its influence on Monte Carlo dose calculations. Med Phys. 2007. 34(6): 2119-32.

[3] Katsura M, Sato J, Akahane M, Kunimatsu A, Abe O. Current and Novel Techniques for Metal Artifact Reduction at CT: Practical Guide for Radiologists. Radiographics. 2018. 38(2): 450-461.

[4] Lell MM, Meyer E, Schmid M, et al. Frequency split metal artefact reduction in pelvic computed tomography. Eur Radiol. 2013. 23(8): $2137-45$.

[5] Morsbach F, Wurnig M, Kunz DM, et al. Metal artefact reduction from dental hardware in carotid CT angiography using iterative reconstructions. Eur Radiol. 2013. 23(10): 2687-94.

[6] Funama Y, Taguchi K, Utsunomiya D, et al. A newly-developed metal artifact reduction algorithm improves the visibility of oral cavity lesions on 320MDCT volume scans. Phys Med. 2015. 31(1): 66-71.

[7] Kidoh M, Utsunomiya D, Ikeda O, et al. Reduction of metallic coil artefacts in computed tomography body imaging: effects of a new single-energy metal artefact reduction algorithm. Eur Radiol. 2016. 26(5): 1378-86.

[8] Gondim Teixeira PA, Meyer JB, Baumann C, et al. Total hip prosthesis CT with single-energy projection-based metallic artifact reduction: impact on the visualization of specific periprosthetic soft tissue structures. Skeletal Radiol. 2014. 43(9): 1237-46.

[9] Hirata K, Utsunomiya D, Oda S, et al. Added value of a single-energy projection-based metal-artifact reduction algorithm for the computed tomography evaluation of oral cavity cancers. Jpn J Radiol. 2015. 33(10): 650-6.

[10] Morsbach F, Bickelhaupt S, Wanner GA, Krauss A, Schmidt B, Alkadhi H. Reduction of metal artifacts from hip prostheses on CT images of the pelvis: value of iterative reconstructions. Radiology. 2013. 268(1): 237-44.

[11] Kidoh M, Nakaura T, Nakamura S, et al. Reduction of dental metallic artefacts in CT: value of a newly developed algorithm for metal artefact reduction (O-MAR). Clin Radiol. 2014. 69(1): e11-6.

[12] Sonoda A, Nitta N, Ushio N, et al. Evaluation of the quality of CT images acquired with the single energy metal artifact reduction (SEMAR) algorithm in patients with hip and dental prostheses and aneurysm embolization coils. Jpn J Radiol. 2015. 33(11): 710-6.

[13] Roth TD, Maertz NA, Parr JA, Buckwalter KA, Choplin RH. CT of the hip prosthesis: appearance of components, fixation, and complications. Radiographics. 2012. 32(4): 1089-107.

[14] Yasaka K, Kamiya K, Irie R, Maeda E, Sato J, Ohtomo K. Metal artifact reduction for patients with metallic dental fillings in helical neck computed tomography: comparison of adaptive iterative dose reduction 3D (AIDR 3D), forward projected model-based iterative reconstruction solution (FIRST) and AIDR 3D with single energy metal artifact reduction (SEMAR). Dentomaxillofac Radiol. 2016 : 20160114.

[15] Shiraishi Y, Yamada Y, Tanaka T, et al. Single-energy metal artifact reduction in postimplant computed tomography for l-125 prostate brachytherapy: Impact on seed identification. Brachytherapy. 2016.

[16] Pulido L, Ghanem E, Joshi A, Purtill JJ, Parvizi J. Periprosthetic joint infection: the incidence, timing, and predisposing factors. Clin Orthop Relat Res. 2008. 466(7): 1710-5.

[17] Andersson KM, Nowik P, Persliden J, Thunberg P, Norrman E. Metal artefact reduction in CT imaging of hip prostheses-an evaluation of commercial techniques provided by four vendors. Br J Radiol. 2015. 88(1052): 20140473.

[18] Huang JY, Kerns JR, Nute JL, et al. An evaluation of three commercially available metal artifact reduction methods for CT imaging. Phys Med Biol. 2015. 60(3): 1047-67.

[19] Kuchenbecker S, Faby S, Sawall S, Lell M, Kachelrieß M. Dual energy CT: how well can pseudo-monochromatic imaging reduce metal artifacts. Med Phys. 2015. 42(2): 1023-36.

[20] Han SC, Chung YE, Lee YH, Park KK, Kim MJ, Kim KW. Metal artifact reduction software used with abdominopelvic dual-energy CT of patients with metal hip prostheses: assessment of image quality and clinical feasibility. AJR Am J Roentgenol. 2014. 203(4): 788-95. 
Tables

Table1 Detailed information of the 31 patients 


\begin{tabular}{|c|c|c|c|c|c|c|c|c|c|c|}
\hline \multirow[t]{3}{*}{$\begin{array}{l}\text { Patient } \\
\text { number }\end{array}$} & \multirow{3}{*}{$\begin{array}{l}\text { Sex } \\
\text { /age } \\
\text { range }\end{array}$} & \multirow{3}{*}{$\begin{array}{l}\text { Primary } \\
\text { tumor }\end{array}$} & \multirow[t]{3}{*}{ Location } & \multirow{3}{*}{$\begin{array}{l}\text { Post- } \\
\text { operative } \\
\text { diagnosis }\end{array}$} & \multicolumn{2}{|c|}{$\begin{array}{l}\text { mean CT attenuation } \\
\pm S D(H U)\end{array}$} & \multicolumn{4}{|c|}{ Visual score } \\
\hline & & & & & \multirow[t]{2}{*}{ IR } & \multirow[t]{2}{*}{ SEMAR } & \multicolumn{2}{|l|}{ IR } & \multicolumn{2}{|l|}{ SEMAR } \\
\hline & & & & & & & $\begin{array}{l}\text { Observer } \\
1\end{array}$ & $\begin{array}{l}\text { Observer } \\
2\end{array}$ & $\begin{array}{l}\text { Observer } \\
1\end{array}$ & $\begin{array}{l}\text { Observer } \\
2\end{array}$ \\
\hline 1 & $\begin{array}{l}M / 45- \\
50\end{array}$ & osteosarcoma & $\mathrm{R}$ & $\begin{array}{l}\text { tumor } \\
\text { recurrence }\end{array}$ & $-54.4 \pm 172.1$ & $37.9 \pm 13$ & 2 & 3 & 4 & 5 \\
\hline 2 & $\begin{array}{l}M / 20- \\
25\end{array}$ & giant cell tumor & $\mathrm{R}$ & $\begin{array}{l}\text { tumor } \\
\text { recurrence }\end{array}$ & $396.7 \pm 180.6$ & $89.6 \pm 14.4$ & 2 & 1 & 4 & 3 \\
\hline 3 & $\begin{array}{l}M / 45- \\
50\end{array}$ & osteosarcomas & $\mathrm{R}$ & $\begin{array}{l}\text { tumor } \\
\text { recurrence }\end{array}$ & $-9.1 \pm 239.6$ & $42.7 \pm 14.8$ & 1 & 2 & 4 & 5 \\
\hline 4 & $\begin{array}{l}M / 20- \\
25\end{array}$ & giant cell tumor & $\mathrm{L}$ & $\begin{array}{l}\text { tumor } \\
\text { recurrence }\end{array}$ & $510.6 \pm 225.5$ & $85.1 \pm 18$ & 1 & 2 & 4 & 5 \\
\hline 5 & $\begin{array}{l}M / 10- \\
15\end{array}$ & osteosarcoma & $\mathrm{L}$ & $\begin{array}{l}\text { tumor } \\
\text { recurrence }\end{array}$ & $366.6 \pm 194.5$ & $46.9 \pm 15.1$ & 0 & 1 & 4 & 5 \\
\hline 6 & $\begin{array}{l}M / 25- \\
30\end{array}$ & giant cell tumor & $L$ & $\begin{array}{l}\text { tumor } \\
\text { recurrence }\end{array}$ & $-219.6 \pm 80.9$ & $114.1 \pm 21.7$ & 2 & 2 & 5 & 5 \\
\hline 7 & $\begin{array}{l}M / 35- \\
40\end{array}$ & giant cell tumor & $\mathrm{R}$ & $\begin{array}{l}\text { tumor } \\
\text { recurrence }\end{array}$ & $-592.5 \pm 205.3$ & $41.5 \pm 22.1$ & 1 & 2 & 4 & 5 \\
\hline 8 & $\begin{array}{l}M / 10- \\
15\end{array}$ & osteosarcoma & $L$ & $\begin{array}{l}\text { tumor } \\
\text { recurrence }\end{array}$ & $917 \pm 202$ & $930 \pm 209$ & 5 & 5 & 5 & 5 \\
\hline 9 & $\begin{array}{l}M / 25- \\
30\end{array}$ & giant cell tumor & $\mathrm{L}$ & $\begin{array}{l}\text { tumor } \\
\text { recurrence }\end{array}$ & $1 \pm 85.1$ & $46.1 \pm 14.6$ & 4 & 3 & 5 & 4 \\
\hline 10 & $\begin{array}{l}M / 25- \\
30\end{array}$ & osteosarcoma & $\mathrm{L}$ & $\begin{array}{l}\text { tumor } \\
\text { recurrence }\end{array}$ & $-7.1 \pm 142.5$ & $27.6 \pm 12.2$ & 2 & 1 & 5 & 4 \\
\hline 11 & $\begin{array}{l}\mathrm{M} / 40- \\
45\end{array}$ & osteosarcoma & $\mathrm{L}$ & $\begin{array}{l}\text { tumor } \\
\text { recurrence }\end{array}$ & $-157.7 \pm 96.2$ & $100.3 \pm 20.6$ & 4 & 3 & 4 & 4 \\
\hline 12 & $\begin{array}{l}M / 25- \\
30\end{array}$ & osteosarcoma & $\mathrm{R}$ & $\begin{array}{l}\text { tumor } \\
\text { recurrence }\end{array}$ & $-325.9 \pm 102.1$ & $20.5 \pm 20.7$ & 1 & 1 & 4 & 3 \\
\hline 13 & $\begin{array}{l}F / 25- \\
30\end{array}$ & Ewing's sarcoma & $\mathrm{R}$ & $\begin{array}{l}\text { tumor } \\
\text { recurrence }\end{array}$ & $8.4 \pm 35.6$ & $19.8 \pm 13.3$ & 4 & 4 & 5 & 5 \\
\hline 14 & $\begin{array}{l}M / 60- \\
65\end{array}$ & $\begin{array}{l}\text { fibrous } \\
\text { histiocytoma }\end{array}$ & $\mathrm{L}$ & $\begin{array}{l}\text { periprosthetic } \\
\text { soft tissue } \\
\text { infection }\end{array}$ & $-46 \pm 104.4$ & $26 \pm 29.3$ & 1 & 2 & 4 & 5 \\
\hline 15 & $\begin{array}{l}F / 40- \\
45\end{array}$ & chondrosarcoma & $\mathrm{R}$ & $\begin{array}{l}\text { periprosthetic } \\
\text { soft tissue } \\
\text { infection }\end{array}$ & $-102.5 \pm 218.2$ & $11.8 \pm 21.6$ & 0 & 1 & 4 & 5 \\
\hline 16 & $\begin{array}{l}M / 45- \\
50\end{array}$ & $\begin{array}{l}\text { aneurysmal bone } \\
\text { cyst }\end{array}$ & $\mathrm{R}$ & $\begin{array}{l}\text { periprosthetic } \\
\text { soft tissue } \\
\text { infection }\end{array}$ & $-208.4 \pm 45.4$ & $46.7 \pm 14.1$ & 0 & 0 & 3 & 3 \\
\hline 17 & $\begin{array}{l}M / 60- \\
65\end{array}$ & chondrosarcoma & $\mathrm{L}$ & $\begin{array}{l}\text { periprosthetic } \\
\text { soft tissue } \\
\text { infection }\end{array}$ & $-139.2 \pm 56.9$ & $-4.8 \pm 39.8$ & 1 & 2 & 4 & 5 \\
\hline 18 & $\begin{array}{l}M / 50- \\
55\end{array}$ & metastatic tumor & $\mathrm{L}$ & $\begin{array}{l}\text { periprosthetic } \\
\text { soft tissue } \\
\text { infection }\end{array}$ & $85.9 \pm 18.7$ & $28.5 \pm 10.4$ & 2 & 1 & 4 & 4 \\
\hline 19 & $\begin{array}{l}M / 50- \\
55\end{array}$ & metastatic tumor & $\mathrm{L}$ & $\begin{array}{l}\text { soft tissue } \\
\text { infection }\end{array}$ & $-70.1 \pm 60.4$ & $28.7 \pm 17.4$ & 0 & 1 & 4 & 5 \\
\hline 20 & $\begin{array}{l}M / 25- \\
30\end{array}$ & osteosarcoma & $\mathrm{L}$ & $\begin{array}{l}\text { fluid } \\
\text { collection }\end{array}$ & $-73.9 \pm 50$ & $-9.3 \pm 18.9$ & 2 & 2 & 5 & 5 \\
\hline 21 & $\begin{array}{l}M / 45- \\
50\end{array}$ & chondrosarcomas & $\mathrm{L}$ & $\begin{array}{l}\text { fluid } \\
\text { collection }\end{array}$ & $233.3 \pm 200.9$ & $39.1 \pm 16.8$ & 0 & 0 & 5 & 5 \\
\hline 22 & $\begin{array}{l}F / 25- \\
30\end{array}$ & osteosarcoma & $\mathrm{L}$ & $\begin{array}{l}\text { fluid } \\
\text { collection }\end{array}$ & $-361.2 \pm 89.8$ & $15.4 \pm 34.9$ & 0 & 1 & 5 & 5 \\
\hline 23 & $\begin{array}{l}M / 40- \\
45\end{array}$ & fibrosarcoma & $\mathrm{L}$ & $\begin{array}{l}\text { fluid } \\
\text { collection }\end{array}$ & $32 \pm 173.5$ & $18 \pm 18.2$ & 1 & 0 & 4 & 3 \\
\hline 24 & $\begin{array}{l}F / 50- \\
55\end{array}$ & metastatic tumor & $\mathrm{R}$ & $\begin{array}{l}\text { fluid } \\
\text { collection }\end{array}$ & $-69.5 \pm 114.7$ & $11.4 \pm 20.6$ & 0 & 0 & 4 & 4 \\
\hline 25 & F/25- & osteosarcoma & $\mathrm{R}$ & fluid & $32 \pm 365.7$ & $29.8 \pm 14.4$ & 0 & 0 & 5 & 5 \\
\hline
\end{tabular}

Page $7 / 9$ 


\begin{tabular}{|c|c|c|c|c|c|c|c|c|c|c|}
\hline & 30 & & & collection & & & & & & \\
\hline 26 & $\begin{array}{l}F / 10- \\
15\end{array}$ & Ewing's sarcoma & $\mathrm{R}$ & $\begin{array}{l}\text { fluid } \\
\text { collection }\end{array}$ & $-31 \pm 15.2$ & $-2.9 \pm 12.3$ & 1 & 2 & 5 & 5 \\
\hline 27 & $\begin{array}{l}\mathrm{F} / 15- \\
20\end{array}$ & Ewing's sarcoma & $\mathrm{R}$ & $\begin{array}{l}\text { fluid } \\
\text { collection }\end{array}$ & $-247.2 \pm 62.6$ & $38 \pm 14.9$ & 0 & 0 & 5 & 5 \\
\hline 28 & $\begin{array}{l}\mathrm{F} / 50- \\
55\end{array}$ & $\begin{array}{l}\text { fibrous } \\
\text { histiocytoma }\end{array}$ & $\mathrm{R}$ & $\begin{array}{l}\text { heterotopic } \\
\text { ossification }\end{array}$ & $-198.3 \pm-419.9$ & $-83.5 \pm 187.9$ & 4 & 4 & 5 & 5 \\
\hline 29 & $\begin{array}{l}M / 40- \\
45\end{array}$ & fibrosarcoma & $\mathrm{L}$ & $\begin{array}{l}\text { heterotopic } \\
\text { ossification }\end{array}$ & $-117 \pm 238.6$ & $109.8 \pm 191.6$ & 0 & 0 & 5 & 5 \\
\hline 30 & $\begin{array}{l}M / 40- \\
45\end{array}$ & chondrosarcoma & $\mathrm{R}$ & $\begin{array}{l}\text { periprosthetic } \\
\text { osteolysis }\end{array}$ & $284.4 \pm 128.7$ & $-76.6 \pm 36.4$ & 1 & 0 & 4 & 4 \\
\hline 31 & $\begin{array}{l}M / 60- \\
65\end{array}$ & chondrosarcoma & $\mathrm{L}$ & $\begin{array}{l}\text { periprosthetic } \\
\text { osteolysis }\end{array}$ & $-70.1 \pm 46.2$ & $21.1 \pm 16.3$ & 1 & 2 & 5 & 5 \\
\hline
\end{tabular}

F: Female; M: Male; R: Right; L: Left; SD: Standard deviation; HU: Hounsfield unit; IR: Iterative; SEMAR: Single energy metal artifact reduction

\section{Figures}

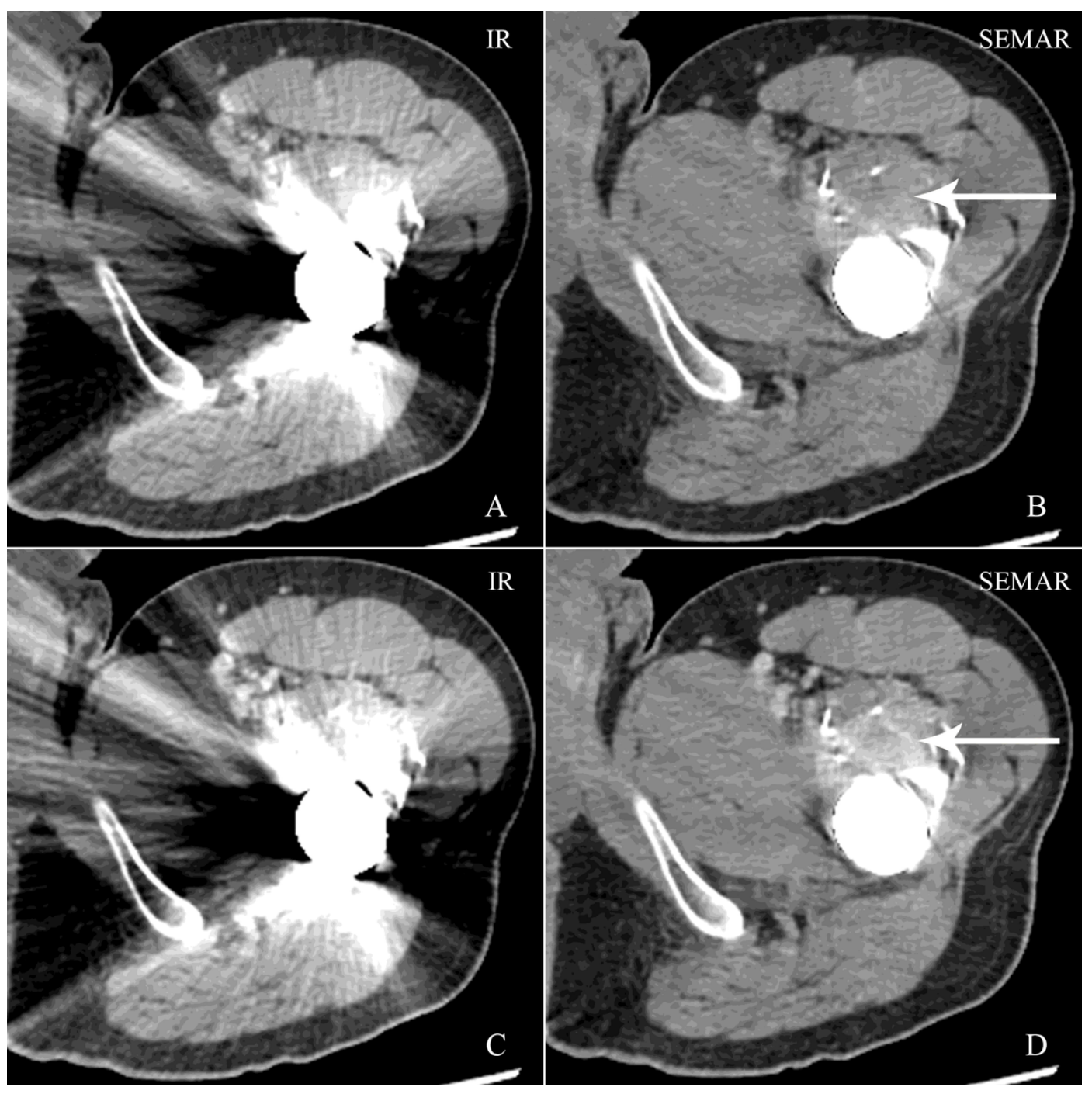

Figure 1

A young man of giant cell tumor recurrence, A-B were unenhanced images and C-D were enhanced images. Images with IR showed substantial black and white streaking artifacts from the protheses, which made the recognition of lesion challenging. On SEMAR images, artifacts were markedly decreased and tumor recurrence was clearly visible(arrow). 


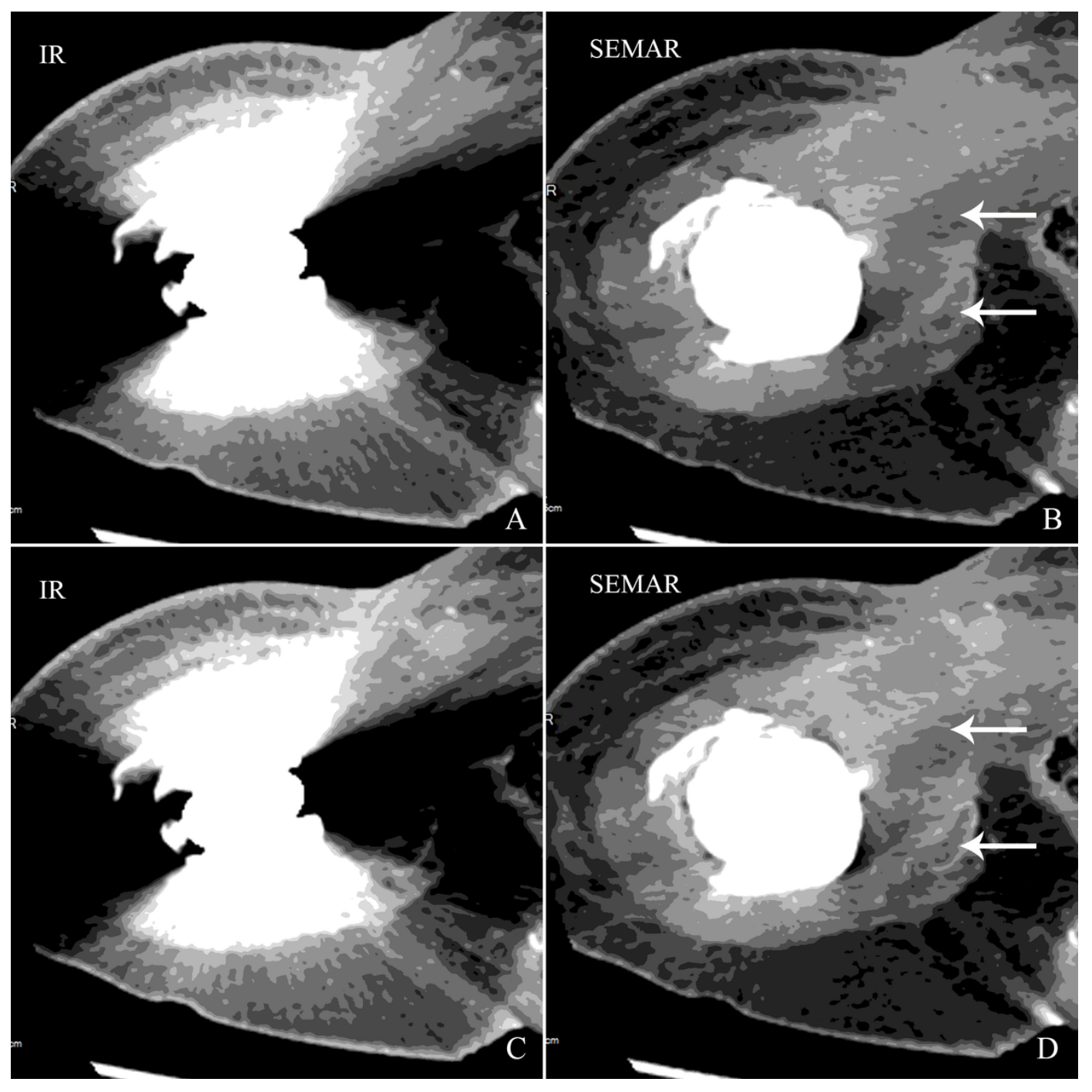

Figure 2

A young man of Ewing's sarcoma, A-B were unenhanced images and C-D were enhanced images. Two abscesses with ring-like enhancement(arrow) were seen, which were almost obscured by prosthetic artifacts on IR images. 